the least, undesirable; whereas by adopting this simple method, after the manner of removing a thorn with the pipe of a key, and producing pressure with an elastic wristlet or slight steel spring like a small truss, the fragment will work out, and not give pain from any knocks while under the skin. In that awkward position, the soft parts by the sides of the ligamentum patellæ, this plan can be used. It recommends itself to everyone's common sense, and has the great advantage of not leaving any cicatrix.

Clifton.

\section{A FAMILY OF DWARFS.}

By G. OSCAR JACOBSEN, M.R.C.S., L.R.C.P.

THE following case of a dwarfish family has come under my notice :-

The dwarfs are three children, two girls and one boy, the father being a well.developed man, height $5 \mathrm{ft}$. 4 in., the mother (his first wife, now dead) having been about $4 \mathrm{ft} .10 \mathrm{in}$. The ages and heights of the children are as follows:-Chas. T. W-, a boy of fourteen years and a half, height $47 \mathrm{in}$. He is a very sharp lad, passed a year back the sixth standard of the School Board, but is generally small. Except for his mental powers he is in every way backward in development, there being no sign of hair about the pubes or axillæe, and his ideas are all rather childish. Nellie W-, eleven years old, height 361 in. The child is fairly sharp, but very puny and delicate, having to be kept away from school during the winter months. Bertha W- , age thirteen years, height $44 \frac{1}{2}$ in. This girl is sharp and has passed the fourth standard, but has no signs of puberty and has never menstruated. I may say that both the girls are knock-kneed, but to no such extent as to make any great difference in height. The boy, thefather tells me, when younger, " had something wrong with his ankles,"which necessitated his being three years in a hospital. In contrast to these d warfed children, I give the heights of the children of the same father by a second wife, who is about the same height as his first wife was. Eva $\mathrm{W}-$, four years old, height $40 \mathrm{in}$, , or $3 \frac{3}{4}$ in. taller than the child of eleven years by the first wife. Lucy W-, eight years old, $44^{1}$ in. in height, being as tall as the child of thirteen years by the first wife. These last two children are also growing yearly, whereas the two dwarf girls have not grown for the last two years. Ann S-, daughter of the second wife by a first husband, is six months younger than the boy dwarf, but is fifteen inches taller, being $5 \mathrm{ft} .2 \mathrm{in}$. in height. She, moreover, has development of mammæ, has hair under the axillæ and on the pubes, and has menstruated for the last three months. The height is not alone wherein the children suffer, but their limbs are all small and in proportion to their miniature size, their heads being rather large. There is no other instance of dwarfs in either the father's or mother's families previous to this, and the mother is said to have always been a healthy woman. The mother was between twenty-four and twentyfive when she married, and had three brothers and three sisters, all of whom married and had healthy children, except one sister. All of the mother's children were born at full term, and no comment was made upon their size.

Huntingdon.

CASE OF CONGENITAL PHIMOSIS, LEADING TO DEATH AT THE AGE OF EIGHTY-THREE.

By arthur S. Taylor, M.B. Cantab., F.R.C.S.

JoHN F-, aged eighty-three, was found dead in a field in which he had been working. I made a post-mortem examination on the coroner's order, and found the following interesting condition :-

Lungs slightly congested with a little old pleurisy on each side. Heart large but healthy. The first part of the aortic arch was dilated, but for a man of eighty-three the artery wall was exceptionally good. Both kidneys were remarkably cystic, with enormously distended pelves and ureters. The bladder was greatly distended by urine, and in two or three places only the peritoneum prevented rupture in to the abdominal cavity. There was no stricture of the urethra, though the middle lobe of the prostate was much hypertrophied. There was congenital phimosis, the circumference of the aperture when slit open and stretched being one inch. On opening the skull, I discovered submeningeal hæmor. rhage covering the base of the brain, running down the vertebral canal, and spreading over both frontal areas. I could discover no small aneurysm, nor the actial vessel which had given way. The interest of the case lies in the slow but sure progress of the disease. Doubtless, the end was hastened by the hypertrophy of the middle lobe of the prostate. At the inquest, the deceased was said to have enjoyed very good health. He had had an attack of dropsy a year previously, and shortly before his fatal apoplexy suffered from epistaxis. The arteries at the base of the brain were rather rigid, but by no means bad. He had had several children.

Surbiton Hill.

\section{a dithror}

\section{HOSPITAL PRACTICE,}

\section{BRITISH AND FOREIGN.}

Nulla autem est alia pro certo noscendi via, nisi quamplurimas et mos borum et dissectionum historias, tum aliorum tum proprias collectas habere, et inter se comparare.-MorgagN De Sed. et Caus. Horb., lib. iv. Proomium

\section{ST. THOMAS'S HOSPITAL.}

TWO CASES OF DISLOCATION OF THE ULNAR NERVE.

THE condition of nerve described in the account of these two cases is one which has not hitherto been recognised in the literature of this country. No mention is made of it in our works on surgery, even when they treat of the subject of nerve injury in a special manner. The only contribution on the subject we can find is one by Dr. F. J. Lutz," who wrote of a case of habitual dislocation of the left ulnar nerve. This account will be read with much interest, more especially the parts which describe the operative measures which were successfully undertaken to secure the nerves in their normal position. For the notes of the cases we are indebted to Mr. E. C. Stabb, surgical registrar.

CASE 1. - E. N-, aged twenty-eight, married, was admitited under the care of $\mathrm{Mr}$. Croft on March 7th, and left the hospital on April 9th, 1891. Six weeks ago the patient fell, grazing her right elbow against the edge of a bucket. This injury was followed by cellulitis, limited to the region of the elbow, and she was admitted to St. Thomas's Hospital twelve days after the injury, and an abscess opened just above the internal condyle of the humerus. She left the hospital well at the end of a week. A few days after this, on commencing to work again, she felt pain on the inner side of the same elbow, shooting down to the hand, whenever she flexed the forearm. On March 7 th she was readmitted, and on examination it was found that on slowly flexing the forearm, when this movement reached to about a right angle, what appeared to be the ulnar nerve slipped forwards over the internal condyle, taking up a position in front of it, and causing pain to the patient. On extending the forearm again the nerve resumed its anatomical position. There was no local tenderness or loss of sensation, or wasting of muscles, but the grasp of the right hand was distinctly more feeble than that of the left. On the 16th Mr. Croft exposed the nerve by a semilunar incision. It was slightly thickened, and freely movable over the internal condyle. He then stitched the sheath of the nerve to the inner margin of the triceps tendon, and finally attached the edge of the same to the periosteum covering the internal condyle, leaving the nerve completely embedded. The arm was fixed in plaster-ofParis splints in the extended position. Theday after theopera. tion the patient complained of sensation of pins and needles in the fourth and fifth fingers. Sensation was almost absent from the fifth finger. The wound healed by first intention, and sensation gradually returned.

On discharge from the hospital the nerve was quite fixed in its normal position. There was no pain on flexion of the

1 St. Louis Medical and Surgical Journal, 1879-80, vol. xxxviii., p. 650. 